https://doi.org/10.18485/unislav.2017.ch2

378.6:[811.161.1+821.161.1(470)"16/19"

371.3::811.161.1(470)"16/19"

\author{
ЛЕОНИД ВИКТОРОВИЧ МОСКОВКИН* \\ Санкт-Петербургский государственный университет \\ Санкт-Петербург, Россия
}

\title{
ПРЕПОДАВАНИЕ РУССКОГО ЯЗЫКА КАК ИНОСТРАННОГО В САНКТ-ПЕТЕРБУРГСКОМ / ЛЕНИНГРАДСКОМ УНИВЕРСИТЕТЕ (XVIII - XX ВВ.)
}

\begin{abstract}
В статье дается краткий обзор истории преподавания русского языка как иностранного в Санкт-Петербургском / Ленинградском университете в XVIII-XX вв. Упоминаются наиболее важные для этой истории персоналии - преподаватели русского языка, руководители подразделений университета. Приводятся данные об основных периодах преподавания русского языка как иностранного в университете, о наиболее известных учебниках, созданных его сотрудниками.

Ключевые слова: русский язык как иностранный, преподавание русского языка, учебники русского языка, Ленинградский государственный университет, Санкт-Петербургский государственный университет
\end{abstract}

\section{1. Петербургский академический университет (XVIIIв.)}

Санкт-Петербургский университет был основан в 1725 году как учебное подразделение Императорской Академии наук и назывался на протяжении всего XVIII века Петербургским академическим университетом. Наряду с университетом в состав Императорской Академии наук входили научные подразделения и академическая гимназия.

В документах, регламентирующих порядок обучения в университете и гимназии, предписывалось преподавать латинский, древнегреческий, немецкий и французский языки. В доношении Академии наук в Сенат в декабре 1724 г. указывалось: «И понеже профессоры и с своими студентами учить будут латынским языком ..., надобно тем уметь латынский язык, или тому прежде обучитися в школе; а иного языка к тому не нужно. Между иными языками весьма нужны: немецкий, французский и греческий: во-первых, что на сих многие обращаются книги, в которых все ведомые науки обретаются; к тому же еще, что немецкий

*moskovkin.leonid@yandex.ru 
и французский в общем житии и обхождении великие дает способия» (Материалы 1885. Т. 1. С. 75-76).

Латинскому языку, первому по значимости в Академии наук, начинали обучать в младших классах гимназии. В старших классах, которые назывались латинской школой, и в университете на латыни преподавали все учебные предметы.

Второе место по значимости занимал немецкий язык, так как академическая гимназия строилась по немецкому образцу, и учителями, в основном, были немцы. Немецкий язык изучался с первого класса, на нем преподавали все учебные предметы в младших классах, которые поэтому и назывались немецкой школой. Немецкий язык выступал в качестве языка-посредника при изучении всех других языков.

Французский язык гимназисты и студенты изучали по желанию. В основном, его преподавали тем, кто планировал в дальнейшем поступить на военную или гражданскую службу. Древнегреческий язык преподавался студентам, которые изучали древности (студиум антиквитатис) и древнюю историю.

В соответствии с регламентом Академии наук преподавание русского языка в университете и в гимназии не предусматривалось, однако у многих учащихся имелась потребность в его изучении. Это было обусловлено двумя обстоятельствами.

Во-первых, предполагалось, что в гимназию будут поступать ученики, владеющие русским языком, умеющие на нем читать и писать. Оказалось, что далеко не все поступавшие в гимназию грамотно писали, а некоторые дети иностранных специалистов еще и плохо говорили порусски. При этом все те, кто в дальнейшем хотел поступить на российскую государственную службу, нуждались в изучении русского языка. Вот почему на протяжении всего XVIII века отмечались попытки ввести его преподавание в гимназии. В 1730-е гг. инспектор гимназии Л. Эйлер предлагал ввести в немецкой школе учебный предмет «русский язык», а инспектор Г.В. Крафт вообще предлагал заменить немецкую школу русской. Эти инициативы не были поддержаны руководством Академии наук. Только в 1758 году М.В. Ломоносов, ставший советником канцелярии Академии наук своим указом заменил немецкую школу русской, но после его смерти в 1765 году начальная школа снова стала немецкой (Кулябко 1962).

Во-вторых, в 1725 г. предполагалось набрать на первый курс Петербургского академического университета учеников российских духовных учебных заведений, владеющих латынью. Однако оказалось, что отобранные абитуриенты не владели латынью как языком науки, и поэтому были зачислены для ее изучения в академическую гимназию. 
В качестве студентов были приглашены иностранцы, обучавшиеся на старших курсах в европейских университетах. Они владели латынью как языком науки, но не владели русским языком, который был необходим для обиходно-бытового общения в Санкт-Петербурге.

Таким образом, уже в первые годы существования Академии наук у гимназистов и студентов имелась потребность в изучении русского языка: русским ученикам было важно научиться грамотно писать, нерусским - еще и правильно говорить по-русски.

В 1720-1730-е гг. для нерусских учеников гимназии занятия по русскому языку проводил вне сетки расписания учитель немецкого и латинского языков М. Шванвиц. Он же для них составил, хотя и только до раздела «Глагол», учебпик русской грамматики. Текст этого учебника был опубликован несколько лет назад Г. Кайпертом и А. Хутерер (Compendium 2002).

Русскому языку обучали и студентов университета. В $1738-1741$ гг. для них курс русской грамматики читал В.Е. Адодуров, в 1750-е гг. российскому штилю обучал студентов С.П. Крашенинников, а в 1760-е годы - А.П. Протасов. В 1780-е гг. директор Академии наук Е.Р. Дашкова проводила со студентами университета занятия по переводу с французского и немецкого языков на русский.

Студент университета В.Е. Адодуров в 1731 г. опубликовал на немецком языке краткую русскую грамматику (Anfangs-Gründe 1731). Это был учебник, по которому преподавали русский язык немцам на протяжении всего XVIII века и который лег в основу ряда учебников русского языка для иностранцев, например, в основу учебника русского языка для немцев Я.М. Родде (Russische Sprachlehre 1773). В 1740-е гг. В.Е. Адодуров обучал русскому языку великую княгиню Екатерину Алексеевну, будущую императрицу Екатерину Вторую, немку по происхождению (Записки императрицы 1907).

Секретарь Академии наук В.К. Тредиаковский в 1720-1730-е гг. работал над грамматикой русского языка для французов (рукопись не обнаружена). Он обучал русскому языку президентов Академии наук Кейзерлинга, Корфа и Бреверна, а также принца Антона-Ульриха Брауншвейгского (Пекарский 1873). На протяжении долгого времени он входил в состав экзаменационной комиссии по русскому языку в Сухопутном шляхетном кадетском корпусе (Материалы 1897. Т. 9. С. 82).

Профессор университета М.В. Ломоносов в 1755 году написал «Российскую грамматику» (Ломоносов 1755), которая стала основой ряда учебников русского языка для иностранцев. Например, на ее основе учитель академической гимназии И.К. Шарпантье составил учебник русского языка для французов (Elemens 1768), который переиздавался 
три раза. Шарпантье обучал русскому языку иностранных дипломатов и членов их семей.

С Императорской Академией наук и Петербургским академическим университетом связана и деятельность первых объединений русистов. В 1735 г. в Академии наук было учреждено Российское собрание комиссия, которая занималась исправлением переводов и ставила цель создания академического толкового словаря, написания академической грамматики и риторики. В Российское собрание входили В.Е. Адодуров, В.К. Тредиаковский, И.К. Тауберт, М. Шванвиц и С.С. Волчков, оно существовало до 1742 г.

В 1748-1760 гг. в Академии наук работало Историческое собрание - комиссия, созданная для рецензирования и обсуждения рукописей книг по гуманитарным наукам и для исправления переводов. Наиболее активными его членами были университетские профессора О.И. Браун, М.В. Ломоносов, Г.Ф. Миллер, В.К. Тредиаковский, Ф.Г. Штрубе де Пирмонт.

В 1783-1841 гг. при Императорской Академии наук работала Российская Академия - общество филологов, которое также ставило цель создания академического словаря русского языка и академической грамматики. В нее входило 78 человек, в том числе и профессора Петербургского академического университета. Первым ее президентом была Е.Р. Дашкова. Члены Российской Академии создали толковый словарь, который содержал 43257 слов (Словарь 1789-1794). В 1802 г. была опубликована академическая грамматика (авторы: П.И. и Д.М. Соколовы при участии протоиерея И.И. Красовского под руководством митрополита Гавриила) (Российская грамматика 1802).

\section{2. Императорский Санкт-Петербургский университет} (XIX в.)

В начале XIX века в результате реформ Петербургский академический университет отделился от Академии наук и в 1819 г. стал самостоятельным учеб̆ым заведением под названием «Императорский Санкт-Петербургский университет». Занятия по русскому языку как иностранному в нем не проводились, но многие преподаватели этого учебного предмета и авторы учебников были связаны с университетом.

Одним из наиболее известныХ в середине XIX века преподавателей русского языка как иностранного был студент юридического факультета В. Алексеев, обучавший русскому языку иностранных дипломатов. Среди его учеников был, в частности, прусский посол Отто фон Бисмарк (Лефельдт 2006). В. Алексеев написал учебник русского языка 
для немцев (Alekseev 1872-1876), который переиздавался 24 раза как в России, так и в Германии.

В 1860-1880-е гг. при университете был открыт Учительский институт славянских стипендиатов. В нем учились студенты-славяне из Германии и Австро-Венгрии, которые готовились стать преподавателями древних языков в российских гимназиях. Русскому языку их обучали несколько преподавателей историко-филологического факультета. Среди них историк русского языка Вячеслав Измайлович Срезневский, который оставил интересные отчеты о методике преподавания русского языка как инославянского, и лермонтовед Иннокентий Михайлович Болдаков (Отчеты 1880. Л. 59 об.).

\section{3. Ленинградский государственный университет $(1945-1990 \text { гг. })^{1}$}

Массовое обучение русскому языку иностранных студентов в Ленинградском университете началось после окончания Великой Отечественной войны - с 1945/46 учебного года, когда в университет прибыли студенты из Албании, Болгарии, Румынии, Чехословакии и Югославии. Организацию обучения этих студентов русскому языку ректорат поручил доценту кафедры русского языка филологического факультета М.А. Соколовой, которая привлекла для проведения учебных занятий преподавателей своей кафедры, кафедр романской и славянской филологии, кафедры фонетики. В составе кафедры русского языка была создана секция русского языка для иностранных студентов (Андреева-Георг 2002).

Прибывавшие в университет студенты из Китая и Монголии направлялись для обучения русскому языку на восточный факультет университета, где занятия с ними проводили преподаватели отделения народов Севера. В 1948 году на основе этого отделения был создан факультет народов Севера, в составе которого в 1949 году была учреждена кафедра методики русского языка для нерусских, заведующий кафедрой: А.А. Горцевский.

6 февраля 1952 г. по решению руководства Ленинградского университета на филологическом факультете была учреждена общеуниверситетская кафедра русского языка для нерусских, которая объединила всех, кто преподавал русский язык иностранным студентам. В 1950-е гг. ее возглавляли А.П. Аверьянова (1952-1956), О.Г. Воронкова (1956-1958), Е.И. Воинова (1958-1959).

${ }^{1}$ В 1924 г. Петроград был переименован в Ленинград. Университет получил название Ленинградский государственный университет. 
Преподаватели кафедры проводили учебные занятия с иностранными студентами I-III курсов и иностранными аспирантами I-II курсов всех факультетов. В 1956 году на кафедре были организованы секции сначала по курсам обучения, а затем и по национальностям: китайская, монгольская, славянская, западная секции, а также аспирантская и филологическая (Аверьянова 2002).

Главной задачей кафедры в области методической работы было создание учебников и учеб̆ых пособий. В 1950-е годы под руководством К.П. Язевой были составлены две книги для чтения и сборник упражнений по синтаксису и развитию речи. В.П. Андреева-Георг и Б.В. Братусь создали учебпик русского языка для 8 класса вьетнамских школ. О.Г. Воронкова, В.Д. Толмачева, Сяо Минь и Цзун Юй-цай опубликовали учебник русского языку для студентов-китайцев.

Научная работа кафедры была направлена на изучение вопросов синтаксиса, лексики и стилистики в аспекте их преподавания студентам-иностранцам. В.П. Андреева-Георг и В.М. Тамань проводили сравнительные исследования русского и родных языков студентов, результаты которых использовались в процессе обучения.

В 1960-е годы общеуниверситетская кафедра русского языка для нерусских, была переименована в кафедру русского языка для иностранцев, заведующие: Б.В. Братусь (1960-1962; 1969-1978) и В.С. Маслов (1962-1969). Она стала крупнейшим в СССР центром научной и методической работы области преподавания русского языка иностранным студентам. Преподавателями разрабатываются пособия по обучению грамматике (Н.П. Кочеткова, В.М. Матвеева, Е.И. Воинова, М.А. Шахматова, А.А. Козлов и др.), фонетике (Б.В. Братусь), развитию речи (В.М. Матвеева, Р.Э. Назариан, Н.П. Колоярцева и др.), стилистике (Л.А. Киселева, В.М. Матвеева, Р.Б. Волосатова и др.), страноведению (Н.А. Куркова, А.Е. Островская Л.В. Гордейчук, Л.П. Даниленко и др.), пособия для краткосрочных курсов (Г.Н. Аверьянова, А.Е. Островская, Н.А. Куркова). Были созданы словарь глагольного управления (В.П. Андреева-Георг, В.Д. Толмачева), словарь словосочетаний (Б.В. Братусь и др.).

Появилось новое направление деятельности кафедры - обучение языку специальности. На кафедре создаются секции естественных наук, гуманитарных наук, филологическая и подготовительная. Для студентов каждого факультета разрабатываются учебные программы и учебные пособия (А.Е. Островская, Л.П. Даниленко, Г.Г. Чупрун, Г.Н. Парилова и др.).

Начиная с 1959 г. примерно один раз в три года издавались сборники научно-методических статей под редакцией Б.В. Братуся, В.С. Маслова, О.Г. Воронковой, Ю.И. Борковского, М.А. Шахматовой. 
Одним из важнейших направлений работы кафедры в 1970-е гг. была подготовка молодых преподавателей русского языка как иностранного. На филологическом факультете было открыто спецотделение, готовившее преподавателей русского языка как иностранного со знанием английского, французского и испанского языков. Специальные дисциплины для них читали преподаватели кафедры русского языка для иностранцев.

В 1978 году на основе кафедры русского языка для иностранцев был учрежден факультет русского языка как иностранного (ФРЯКИ). Деканы факультета: В.М. Мокиенко (1979-1990), К.А. Рогова (1990-1994). На факультете были созданы:

- кафедра русского языка для студентов-филологов, заведующие кафедрой: В.И. Кодухов (1978-1984), К.А. Рогова (1984-1993),

- кафедра русского языка для иностранных учащихся гуманитарных факультетов, заведующие кафедрой: Г.Н. Аверьянова (1978-1982), В.М. Мокиенко (1982-1990);

- кафедра русского языка для иностранных учащихся естественных факультетов, заведующие кафедрой: Л.П. Даниленко (1980-1982), А.И. Моисеев (1982-1993);

- кафедра краткосрочных форм обучения иностранцев русскому языку, заведующая кафедрой Г.Н. Аверьянова (1982-1990 гг.);

- кафедра страноведения СССР, заведующая кафедрой: Н.А. Куркова (1985-1990).

ФРЯКИ обеспечивал практическое преподавание русского языка как иностранного на всех факультетах университета, преподавание на краткосрочных курсах, а также подготовку студентов спецотделения.

В 1980-е гг. на новый уровень поднялась научная работа преподавателей. Один раз в два года издавались сборники научных статей под редакцией Г.Н. Аверьяновой, Л.П. Даниленко, В.И. Кодухова, А.И. Моисеева, В.М. Мокиенко, К.А. Роговой, В.В. Химика, С.Ф. Шатилова. Был опубликован ряд методических работ (Любимова 1982; Шатилов 1985; Кодухов 1985; Волосатова, Малехова 1988; Ендольцев 1988; Грамматика 1991).

В 1981 г. была открыта аспирантура, которая готовила научные кадры высшей квалификации по специальностям 10.02.01 - Русский язык и 13.00.02 - Методика обучения русскому языку как иностранному. До 1983 г. аспирантурой руководила М.А. Шахматова, с 1983 г. по настоящее время - Н.А. Любимова. Лекции для аспирантов читали В.И. Кодухов, Н.А. Любимова, А.И. Моисеев, В.М. Мокиенко, С.Ф. Шатилов, М.А. Шахматова. 
В 1983 г. Высшая аттестационная комиссия СССР утвердила в Ленинградском университете специализированный совет по защите кандидатских диссертацией по двум указанным научным специальностям. Председатели совета: В.И. Кодухов (1983-1985), В.М. Мокиенко (1985-1990), К.А. Рогова (1990-2013). Первые защиты кандидатских диссертаций состоялись в 1984 году.

Самым крупным методическим достижением 1980-х гг. было создание учебного комплекса по русскому языку для иностранных студентов-филологов. В работе над основными учебниками для первого и второго годов обучения приняли участие Г.Н. Аверьянова, Е.И. Войнова, В.М. Матвеева (Учебник 1983), в работе над учебными пособиями - Н.П. Кочеткова, Р.Э. Назариан, Ю.И. Борковский, В.М. Ласкарева, В.М. Матвеева, С.Т. Саевич, М.А. Шахматова и другие.

Разрабатывались учебные пособия по фонетике (Б.В. Братусь, Л.А. Вербицкая), грамматике, стилистике, языку специальности. Создается учебная программа для краткосрочных курсов и ряд учебных пособий, среди которых получил известность учебник «Темп-3» (1983).

\section{4. Санкт-Петербургский государственный университет (с 1992 г. по настоящее время) ${ }^{2}$}

В 1990-е гг. Факультет русского языка как иностранного прекращает свое существование. В 1990 г. на базе кафедры краткосрочных форм обучения иностранцев русскому языку и кафедры страноведения создается Центр русского языка и культуры (первый директор - А.С. Филиппов, затем С.Г. Еремеев). В 1993 г. три остальные кафедры вливаются в состав филологического факультета Санкт-Петербургского государственного университета. В ходе преобразований формируются:

- кафедра русского языка для иностранцев-филологов, в дальнейшем кафедра русского языка как иностранного и методики его преподавания; заведующие кафедрой: К.А. Рогова (1993-1999 гг.), Е.Е. Юрков (1999-2013 гг.), В.П. Казаков (2013-2017 гг.), Е.И. Зиновьева (2017 г.), Т.И. Попова (2017 г. - по настоящее время);

- кафедра русского языка для иностранцев-нефилологов, в настоящее время кафедра русского языка для гуманитарных и естественных факультетов; заведующие кафедрой: В.В. Химик (19932016 гг.), Е.И. Селиверстова (с 2016 г. по настоящее время).

2 Ленинградский государственный университет в 1992 г. получил название СанктПетербургский государственный университет (СПбГУ). 
За прошедшие 24 года преподавателями этих кафедр сделано так много, что все это трудно описать в рамках одной статьи. Отметим основные позиции.

В 1990-2000-е гг. кафедры русского языка как иностранного начали заниматься проблемами теории и практики сертификационного тестирования. В 1997 году в СПбГУ учреждается Центр тестирования граждан зарубежных стран по русскому языку. Создаются государственные образовательные стандарты по русскому языку как иностранному, типовые тесты с ориентацией на высшие уровни владения языком, методические пособия по тестированию. Проблемам оценки коммуникативной компетенции иностранных учащихся посвящаются научные исследования И.Н. Ерофеевой, О.А. Лазаревой, Т.Е. Нестеровой, Т.И. Поповой, Н.Л. Федотовой, Е.Е. Юркова и других специалистов.

Под руководством Н.А. Любимовой проводится серия исследований фонетической стороны русской речи, создается ряд монографий (см., например, Любимова 2011). К.А. Рогова руководит группой исследователей текста, ими издается несколько коллективных монографий по теории текста и методике работы с текстом на занятиях по русскому языку как иностранному (см., например, Текст 2011). Создается ряд монографий и учебных пособий в области лексикологии и лингвокультурологии под руководством Е.И. Зиновьевой (см., например, Зиновьева 2010). Публикуются монографии по фразеологии и паремиологии (Е.И. Селиверстова), фольклору (А.В. Никитина), литературоведению (Н.П. Беневоленская, Л.Д. Бугаева). В.В. Химик исследует разговорную речь и издает «Большой словарь русской разговорной экспрессивной речи» и «Толковый словарь русской разговорно-обиходной речи». Н.А. Буре принимает участие в составлении «Словаря перестройки» под руководством В.И. Максимова.

Публикуется монографические исследования в области методики обучения русскому языку как иностранному (Капитонова, Московкин 2006; Московкин, Щукин 2013; Лазарева 2012). Издается учебный комплекс по методике Н.Л. Федотовой, включающий учебное пособие и практикум (Федотова 2015). Под руководством Т.И. Поповой осуществляются лингводидактические описания уровней владения русским языком, создаются учебные программы.

Результаты научных исследований преподавателей русского языка как иностранного находят отражение в кандидатских и докторских диссертациях, представляются и обсуждаются на ежегодной международной филологической конференции СПбГУ, где на протяжении многих лет готовит и проводит секцию «Русский язык как иностранный и методика его преподавания» Н.А. Любимова. 
За последние 25 лет сотрудники кафедр русского языка ка иностранного СПбГУ подготовили около 120 учебников и учебных пособий для иностранных учащихся. Среди них учебные комплексы «Русское поле» (2008), «Русский язык. Первые шаги» (2010), «Успех» (2011), «Русский язык для продвинутых» (2014).

Пользуются популярностью не только в СПбГУ, но и за его пределами пособия по обучению фонетике Н.Л. Федотовой, грамматике Б.Н. Коваленко, О.И. Глазуновой, Е.Р. Ласкаревой, лексике Е.Р. Ласкаревой, письму Д.В. Колесовой, Н. Масловой, аудированию И.А. Гончар, Л.И. Москвитиной, говорению Т.И. Поповой и Е.Е. Юркова, О.В. Хорохординой, страноведению И.А. Гончар, Е.Н. Зыковой Е.Р. Ласкаревой, А.В. Никитиной, Л.Б. Волковой и Т.А. Комиссаровой, языку специальности А.С. Шатилова.

Одним из направлений учебно-методической деятельности кафедр является освоение и применение новых информационных технологий и создание сетевых дистанционных учебных курсов. Преподавателями кафедры русского языка для гуманитарных и естественных факультетов Н.А. Буре, М.В. Быстрых, Л.Б. Волковой, М.Ф. Лужковской, И.Г. Никольской, Е. И. Зыковой, Е. И. Селиверстовой разработаны сетевые дистанционные курсы в системе Moodle - «Русский язык как иностранный в профессиональной сфере (гуманитарный и естественный профили»); «Речевой портрет делового человека»; «Русский язык от А до Я. Первая встреча»; в системе Blackboard - «Русский язык и культура речи» (Н.А. Буре). Изданы лингводидактические тренажеры «Формула счастья» (2007) и «Люблю тебя» (2009) (М.В. Быстрых, Н.А. Буре). На кафедре русского языка как иностранного и методики его преподавания подготовлен дистанционный курс «Успех+» (О.И. Глазунова, Т.И. Попова и др.).

Одним из направлений работы кафедр русского языка как иностранного СПбГУ является участие в разработке и проведении программ дополнительного образования. Среди них программы «Преподавание русского языка как иностранного - второе образование», «Лингводидактическое тестирование», «Текст - объект языка, речи, коммуникативно ориентированного обучения русскому языку как родному и как иностранному».

В 2005 г. в составе филологического факультета был создан Институт русского языка и культуры (директор - Е.Е. Юрков, с 2013 г. -В.П. Казаков), который координировал научную и учебно-методическую работу кафедр русского языка как иностранного и осуществлял подготовку иностранных учащихся разных уровней владения русским языком (Институт существовал до 2015 г.). В 2015 г. на его основе был создан Центр дополнительных образовательных программ по направлению «Русский язык как иностранный» (руководитель - О.В. Чухаева). 
Кафедры русского языка как иностранного СПбГУ сотрудничают с российскими и зарубежными вузами, с общественными организациями. Их выпускники работают в вузах России и других стран на всех континентах планеты.

\section{ЛИТЕРАТУРА}

Аверьянова А.П. История общеуниверситетской кафедры русского языка для нерусских // Филологический факультет Санкт-Петербургского государственного университета / Сост. И. С. Лутовинова; Отв. Ред. С. И. Богданов. 3-е изд., испр. и доп. СПб.: Филологический факультет Санкт-Петербургского государственного университета, 2002. С. 170-173.

Андреева-Георг В.П. Общеуниверситетская кафедра русского языка (исторический очерк) // Филологический факультет Санкт-Петербургского государственного университета / Сост. И. С. Лутовинова; Отв. Ред. С. И. Богданов. 3-е изд., испр. и доп. СПб.: Филологический факультет СанктПетербургского государственного университета, 2002. С. 168-170.

Волосатова Р.Б., Малехова А.Н. Методика преподавания русского языка как иностранного: Курс лекций. Л.: ЛГУ, 1988. 53 с..

Грамматика в практическом курсе русского языка как иностранного / В.В. Химик и др. Л.: ЛГУ, 1991. 86 с.

Ендольцев Ю.А. Вопросы теории и практики в преподавании лингвострановедения. Л. : ЛГУ, 1988. 52 с.

Записки императрицы Екатерины Второй. Пер. с подлинника, изд. Имп. Академией наук. СПб., 1907.

Записки императрицы Екатерины Второй: перевод с подлинника, изданного Императорской Академией наук. СПб.: изд. А.С. Суворина, 1907. 749 с.

Зиновьева Е.И. Русская ментальность в зеркале языка: учебное пособие. СПб.: Нестор-История, 2010. 96 с.

Капитонова Т.И., Московкин Л.В. Методика обучения русскому языку как иностранному на этапе предвузовской подготовки. СПб.: Златоуст, 2005. 135 с.

Кодухов В.И. Русский язык как иностранный. Л.: ЛГУ, 1985. 63 с.

Кулябко Е.С. М.В. Ломоносов и учебная деятельность Петербургской Академии наук. М.-Л.: Изд. Академии наук СССР, 1962. 216 с.

Лазарева О.А. Лингвокогнитивные основы обучения иностранцев русской лексике. СПб: издательство «Осипова», 2012. 250 с.

Лефельдт В. Бисмарк и русский язык // Вереница литер: К 60-летию В.М. Живова. Отв. ред. А.М. Молдован. М.: Языки славянской культуры, 2006. С. 449-469.

Ломоносов М.В. Российская грамматика. СПб.: типогр. ИАН, 1755 (1757). 210 с.

Любимова Н.А. Лингвистические основы обучения артикуляции русских звуков. М.: Русский язык, 2011. 242 с.

Любимова Н.А. Обучение русскому произношению: Артикуляция. Постановка и коррекция рус. звуков. 2-е изд. М.: Русский язык, 1982. 190 с. 
Материалы для истории Императорской Академии наук. Т. 1. (1716-1730). СПб.: типогр. ИАН, 1885. 732 с.

Материалы для истории Императорской Академии наук. Том IX. (1748-1749). СПб.: типогр. ИАН, 1897. 827 с.

Московкин Л.В., Щукин А.Н. История методики обучения русскому языку как иностранному. М.: Русский язык. Курсы, 2013. 400 с.

Отчеты об учительском институте славянских стипендиатах за время от 21 января 1866 по 1 января 1880 года // Российский государственный исторический архив (РГИА). Ф. 733. Оп. 169. Ед. хр. 13.

Пекарский П.П. История Императорской Академии наук в Петербурге. Том 2. СПб.: типогр. ИАН, 1873. 2012 с.

Российская грамматика, сочиненная императорской Российской академиею. СПб.: Имп. Тип., 1802. 355 с.

Русский язык. Первые шаги: учебное пособие: в 3 ч. / Л.Г. Беликова, Т.А. Шутова, С.Б. Степанова. СПб.: МИРС, 2010. 584 с.

Русский язык. Учебник для продвинутых / Рогова К.А., Вознесенская И.М., Хорохордина О.В., Колесова Д.В. Вып.1. СПб.: Златоуст, 2014. 204 с.

Русское поле. Книга для студента. II сертификационный уровень общего владения РКИ. Ч.1 / И.М. Вознесенская, И.А. Гончар, Т.И. Попова, Н.Л. Федотова; под ред. Е.Е. Юркова. СПб.: МИРС, 2008. 197 с.

Словарь Академии Российской 1789-1794 : В 6 т / Рос. акд. наук. Отд-ние лит. и яз., Моск. гуманит. ин-т им. Е.Р. Дашковой. Переизд. М. : МГИ, 2001.

Текст: теоретические основания и принципы анализа / Под ред. К.А. Роговой. СПб.: Златоуст, 2011. 456 с.

Темп-3 : Интенсивный курс русского языка / Аверьянова Г.Н., Колоярцева Н.П., Куркова Н.А., Пядусова Г.И. М.: Русский язык, 1983. 238 с.

Успех. Элементарный уровень. Книга для студента / Е.Е. Юрков, Л.В. Московкин, И.А. Бойцов и др.; под ред. Е.Е. Юркова, Л.В. Московкина. СПб.: МИРС, 2011. $141 \mathrm{c}$.

Учебник русского языка для иностранных студентов-филологов : Основной курс (первый год обучения) / Войнова Е.И., Матвеева В.М., Аверьянова Г.Н. М.: Русский язык, 1981. 311 с.

Федотова Н.Л. Методика преподавания русского языка как иностранного (практический курс). СПб. : Златоуст, 2015. 192 с.

Шатилов С.Ф. Актуальные проблемы методики обучения русскому языку иностранных учащихся. Л.: ЛГУ, 1985. 56 с.

Alekseev V. Neues Lehrbuch der Russischen Sprache mit beigefügten Sprechübungen und Lesestücken. St.Petersburg, 1872-1876. 346 c.

Anfangs-Gründe der Russischen Sprache // Нъмецко-латинскій и рускій Лексиконъ купно съ первыми началами рускаго языка къ общей пользъ при Імператорской Академіи наукъ печатію изданъ. СПб.: типогр. ИАН, 1731. С. 1-48.

Compendium Grammaticae Russicae (1731). Die erste Akademie-Grammatik der russischen Sprache / Hrsg. Von H. Keipert in Verbindung mit A. Huterer. Munchen: Verlag der Bayerische Akademie der Wissenschaften in Kommission beim Verlag C.H. Beck, 2002. 219 S. (Bayerische Akademie der Wis- 
senscaften. Philosophisch-Historische Klasse. Abhandlungen. Neue Folge. Heft 121).

Elemens de la langue russe ou Méthode courte et facile pour apprendre cette langue conformément à l'usage. Saint-Pétersbourg, de l'Imprimerie de l'Académie Impériale des Sciences. 1768. 368 p.

Russische Sprachlehere, zum Besten der deutschen Jugend eingerichtet von Jacob Rodde, Secretair und Translateur des Magisträts in Riga. Riga : Bey Johann Friedrich Hartknoch, 1773. 248 c.

Leonid Viktorovich Moskovkin

\author{
TEACHING RUSSIAN AS A FOREIGN LANGUAGE AT THE SAINT \\ PETERSBURG / LENINGRAD STATE UNIVERSITY \\ $\left(18^{\mathrm{TH}}-20^{\mathrm{TH}}\right.$ CENTURIES)
}

\title{
Summary
}

The article deals with the brief survey of the history of teaching Russian as a foreign language in the Saint Petersburg / Leningrad State University (18th - 20th centuries). The most important personalia - the Russian language teachers, the chiefs of departments of the university - are mentioned. The data about the different periods of teaching Russian as a foreign language, the famous Russian language textbooks are given.

Key words: Russian as a foreign language, teaching Russian language, Russian language textbooks, Saint Petersburg State University, Leningrad State University 